\title{
BUDAYA PERCEPATAN DAN PERCEPATAN BUDAYA
}

\author{
Ivan Kurniawan \\ Program Studi Desain Komunikasi Visual, Universitas Komputer Indonesia
}

\begin{abstract}
Abstrak. Sepanjang sejarah kehidupan, manusia selalu berusaha untuk mencari solusi terkait masalah yang dihadapinya. Dalam perkembangan peradaban, manusia telah berhasil menemukan teknik-teknik untuk meningkatkan kualitas hidupnya, diantaranya berupa teknologi dan desain. Saat ini teknologi bukanlah sesuatu yang asing bagi masyarakat. Dalam kehidupan sehari-hari, masyarakat acap kali bersinggungan dengan hal yang terkait dengan teknologi. Teknologi telah menghadirkan solusi untuk mempermudah hidup, mempersingkat perjalanan, dan menyederhanakan proses. Namun dibalik kemudahan yang ditawarkannya, ternyata ada hal-hal negatif yang dapat ditimbulkan oleh teknologi. Fenomena asosial, penyerapan budaya luar, dan revolusi gaya hidup telah begitu merebak dalam masyarakat. Hal tersebut tentu tidak lepas dari peran teknologi yang memudahkan dan mempercepat aktifitas manusia. Sekat ruang dan waktu dirasa telah mulai pudar. Batas-batas geografis juga tidak mampu untuk membendung arus informasi yang ada. Kondisi tersebut tentu akan mengakibatkan pergeseran pada budaya masyarakat. Secara khusus artikel ini akan membahas mengenai potensi teknologi dan desain dalam memberi pengaruh pada perubahan budaya masyarakat melalui teori dromologi yang diungkapkan oleh Paul Virillo.
\end{abstract}

Kata kunci: budaya, percepatan

\section{PENDAHULUAN}

Kesibukan, sebuah kata yang sarat makna akan banyaknya aktifitas seseorang. Dalam pemaknaan lain, kesibukan dapat dipandang pula sebagai akibat dari ketidakmampuan manusia untuk memanipulasi ruang dan waktu. Manusia sering merasa tidak memiliki waktu yang cukup untuk menyelesaikan pekerjaannya, baik itu terkendala oleh proses kerja yang panjang dan sulit, jarak yang harus ditempuh, maupun keterbatasan dalam bidang keilmuan. Kendala-kendala tersebut telah memicu manusia untuk melakukan inovasi dan menemukan teknik yang bertujuan untuk memberi kemudahan dalam mencapai suatu tujuan yang disebut juga dengan teknologi. 
Pada dasarnya, teknologi bukanlah hal yang asing lagi bagi masyarakat. Segala kegiatan dalam kehidupan sehari-hari acap kali bersinggungan dengan teknologi. Perkembangan teknologi yang pesat pada masa modern hingga sekarang telah memberikan pengaruh pada pola kehidupan masyarakat. Teknologi telah berhasil mewujudkan kemudahan-kemudahan, seperti percepatan proses penyebaran informasi, kemudahan bertransportasi, dan kemudahan lainnya. Teknologi telah menawarkan sebuah kenyataan baru mengenai ruang dan waktu dalam kehidupan manusia.

\section{METODE DAN PEMBAHASAN}

\section{Perubahan Budaya Masyarakat}

Perpaduan antara desain dan teknologi diyakini telah memicu terjadinya lompatan-lompatan proses berfikir dan proses beraktifitas. Penyediaan barangbarang kebutuhan dapat dilakukan dalam skala yang besar dan waktu singkat melalui proses pabrikasi. Proses pendistribusian produk pun berlangsung singkat sebagai imbas dari kemajuan dibidang transportasi. Sehingga menciptakan suatu kondisi dimana kehidupan masyarakat telah terkepung oleh objek-objek desain. Pola dan intensitas interaksi masyarakat dengan desain menjadi semakin intim. Menyentuh mulai dari cakupan kegiatan masyarakat yang bersifat luas hingga pada tataran aktivitas pribadi. Dan secara langsung maupun tidak, akan menyebabkan perubahan sosial budaya pada masyarakat.

Proses pabrikasi dan distribusi produk desain yang cepat telah memberikan pengaruh perilaku budaya konsumtif. Sebagai contoh, perubahan model pada sebuah seri handphone dalam waktu yang cepat telah memberikan efek 'ketinggalan model' pada benak masyarakat. Masyarakat merasa selalu tertinggal dan berusaha mengejar ketertinggalannya dengan model yang baru. Padahal jika dilihat dari sisi fungsionalitasnya, handphone dengan model apapun sejatinya digunakan untuk berkomunikasi dengan audio dan visual berupa pesan singkat. Pergantian model secara cepat dan bertahap pada sebuah produk industri akan 
memberikan ilusi waktu atas kekinian. Seperti yang diungkapkan oleh Slade (2007, p. 5) "...mechanism of changing product style as a way to manipulate consumers into repetitive buying".

Cepatnya penyebaran informasi juga dapat mempengaruhi pola konsumtif masyarakat. Iklan sebagai salah satu hasil dari proses desain yang memberikan pengaruh pada pola pikir pemirsanya ${ }^{1}$, dapat disebarkan secara luas dan dalam waktu yang bersamaan melalui teknologi broadcast dan jaringan internet. Bujukan, rayuan, bahkan ideologi makin mudah tersebar kepada masyarakat luas, hingga berpotensi merubah gaya hidup masyarakat. Iklan tidak lagi bersifat lokal, kini iklan dapat bersifat global. Hal tersebut dapat dilihat pada iklan-iklan produk kecantikan yang tayang di televisi. Iklan tersebut tidak lagi diproduksi ulang untuk memenuhi kesesuaian dengan budaya lokal, namun cukup dengan proses dubbing untuk penggantian bahasa saja. Kondisi demikian tentunya akan menyebabkan sebuah proses perubahan, percampuran, atau bahkan pengeliminasian budaya yang tak mampu bertahan. Nilai-nilai dan budaya baru akan diserap oleh masyarakat melalui produk-produk desain yang 'dipersepsikan' dan dikonsumsinya. Hingga pada akhirnya masyarakat disuatu daerah akan tercabut identitasnya dan melebur pada identitas global. Proses manufaktur dan produksi masal produk-produk desain juga memiliki andil yang besar dalam penyampaian nilai-nilai universal pada suatu budaya tertentu. Dengan sifat industri yang masif, akan mustahil mengakomodir nilai-nilai yang bersifat lokal. Alasan ekonomi dan biaya produksi seolah melegalkan desain yang mengusung nilai-nilai budaya global.

Kelebihan desain dalam memberikan 'nilai' pada sebuah objek juga dapat menjadi masalah tersendiri. Nilai-nilai tersebut 'diadopsikan' dan dipraktekkan dalam kehidupan masyarakat lebih kepada sebagai sebuah status sosial. Posisi

\footnotetext{
${ }^{1}$ Grimaldi, Joe. Inside the Minds: The Art of Advertising: CEOs from BBDO, Mullin Advertising \& More on Generating Creative Campaigns \& Building Successful Brands. (Aspatore Books : 2003). hal. 1.
} 
individu dalam sebuah struktur masyarakat dapat dipetakan dengan mudah melalui objek desain. Cukup dengan bentuk, material, atau bahkan dengan warna. Desain telah membentuk susunan kasta dan kotak-kotak posisi individu dalam masyarakat. Desain tidak lagi sebagai solusi substansial sebuah permasalahan yang dihadapi manusia, melainkan telah berubah menjadi posisi sosial. Mempengaruhi cara berpenampilan dalam keseharian hingga pada memproduksi citra individu secara luas. Banyak figur-figur masyarakat yang muncul dengan cepat melalui sebuah sensasi yang diproduksi melalui media internet. Sensasi-sensasi tersebut hadir silih berganti dengan cepat dan tanpa kontrol sosial masyarakat. Nilai-nilai yang hadir dalam bentuk visual dapat tercerap dan mendapatkan perhatian, atau bahkan langsung ditiru oleh sebagian masyarakat yang lain. Sensasi menjadi sebuah komoditi yang memiliki nilai jual tinggi mengalahkan norma dan struktur nilai sosial. Hal ini dapat dilihat dari makin cepatnya idola-idola baru muncul dan kemudian hilang begitu saja, acara yang sarat dengan pesan moral makin terpinggirkan oleh acara hura-hura dan ajang unjuk bakat yang menjanjikan ketenaran.

Kehadiran internet juga telah membuat masyarakat seperti memiliki gerbang besar menuju informasi yang cepat. Kini masyarakat tak perlu mencari informasi, justru keadaan telah berbalik dimana informasi yang mendatangi. Siap maupun tidak, masyarakat dipaksa untuk mengkonsumsinya. Keadaan ini akan membuat sekat-sekat geografis seperti hilang. Perbedaaan wilayah geografis, teritorial negara, dan perbedaan zona waktu bukan penghalang bagi laju informasi. Kejadian peperangan di Irak, dapat disaksikan oleh masyarakat di Indonesia. Pertandingan sepak bola yang disiarkan secara langsung juga membuat masyarakat tercabut dari realitas dunia nyata. Masyarakat dapat mengikuti peristiwa, bahkan merasakan emosi yang sama dengan masyarakat lain dalam rentang wilayah geografis dan zona waktu yang berbeda. 
Hal lain yang perlu dicermati adalah kondisi dimana teknologi semakin menyatu dengan objek desain. Teknologi semakin pintar dan mampu dibalut oleh kemasan desain tanpa terlihat. Bahkan pada kondisi tertentu teknologi dapat memanipulasi kondisi lingkungan demi kemudahan manusia. Remote, escalator, mobil, hingga pesawat terbang telah mampu menghadirkan kepraktisan, sifat instan, dan manipulasi alam. Memanjakan ego manusia untuk meraih tujuan dengan cara yang mudah dan memfasilitasi kelemahan manusia. Sifat instan telah memicu sebuah budaya ketergesaan pada masyarakat, mengakibatkan rasa resah akan kungkungan tirani 'waktu' yang berubah cepat. Dalam hal komunikasi, penggunaan social media juga telah merubah tata nilai pada masyarakat. Dengan kepraktisannya, social media telah menggantikan budaya tatap muka pada sebuah tempat tertentu dengan cukup duduk diam di depan komputer yang terhubung internet. Orasi-orasi budaya dan ideologi tidak perlu lagi ditampilkan diatas sebuah mimbar, cukup dengan 'kicauan-kicauan' twitter. Budaya silaturahmi dan saling mengunjungi telah diwakilkan oleh 'temboktembok' facebook. Kondisi ini telah memunculkan salah satu budaya berdiam diri yang disebut budaya sedentaryness ${ }^{2}$, sebuah bentuk budaya untuk diam berlama-lama dalam suatu tempat dan posisi yang sama ${ }^{3}$. Tentunya budaya tersebut akan memberi efek pada masyarakat baik secara fisik maupun tatanan nilai. Kemampuan otot dan gerak manusia akan menurun hingga menyebabkan obesitas atau bahkan kerusakan pada jaringan otot.

\section{KESIMPULAN}

Teknologi memang diciptakan untuk membantu manusia dalam memecahkan masalah. Banyak hal-hal yang positif dari teknologi, berkat ditemukannya teknologi, manusia telah mampu memanipulasi ruang dan waktu. Membuat jarak makin mendekat hingga pada tahap memasukkannya dalam objek desain seperti handphone dan mini komputer. Membuat waktu yang dibutuhkan untuk

\footnotetext{
2 virillo

${ }^{3}$ Karaiskos, et al. 2010
} 
sebuah proses produksi semakin singkat melalui manufaktur dan pabrikasi. Teknologi telah berhasil menghadirkan sebuah 'percepatan'. Namun kuasa yang seharusnya membuat manusia memiliki banyak waktu bagi kehidupannya, ternyata justru membuat aktifitas manusia makin padat. Teknologi menjadi seperti bukan sebuah solusi akhir bagi manusia terkait permasalahannya dengan ruang dan waktu. Hingga saat ini, masyarakat masih larut dalam berbagai kesibukan. Justru kesibukan pada masa sekarang tampak melebihi kesibukan aktifitas pada masa-masa sebelumnya ${ }^{4}$. Manusia makin berlomba untuk meraih pengaruh pada dunia dengan memanfaatkan percepatan. Manusia telah berpindah dari budaya kronologis menjadi budaya kronoskopik ${ }^{5}$ dengan ikut memunculkan perubahan perspektif dan karakteristik sosialnya. Memunculkan budaya instan, memunculkan anxiety (keresahan), kehilangan posisi geografis, hidup dalam zona waktu global, terlarut dalam budaya asing, distorsi akan prinsip dunia nyata, hingga menimbulkan kerusakan pada tubuh manusia.

Desain memiliki sejarah yang panjang dalam kehidupan manusia. Melihat pada proses perkembangannya melalui serangkaian thesa, antithesa, hingga menjadi sinthesa dan berlanjut pada thesa dan seterusnya, tak ubahnya melihat serangkaian mata rantai yang terus menyambung tanpa henti ${ }^{6}$. Tiap-tiap proses dan hasil desain mungkin tidak akan menjadi sebuah solusi yang absolut benar. Namun pada tiap-tiap mata rantai tersebut, diharapkan pada tiap-tiap desain yang hadir mampu untuk memberikan kontribusi positif terhadap perilaku dan budaya masyarakat. Bukan semata-mata menjadi mesin-mesin yang bertugas mencapai tujuan industri dan memenuhi paham kapitalis. Selain membendakan ide-ide abstrak yang merujuk pada kemudahan dan keindahan bagi masyarakat. Desain juga sebaiknya mampu menanamkan nilai-nilai positif pada masyarakat. Sebaiknya desain tidak hanya berkutat pada 'cara membungkus' teknologi

\footnotetext{
4 ed. Hartmut, Rosa, and Scheuerman, William, E.. High-speed society : social acceleration, power, and modernity. ( The Pennsylvania State University Press : 2009). Hal 288.

5 Purser, Ronald, E. The coming crisis in real-time environments: a dromological analysis. Hal. 4.

${ }^{6}$ Heskett, John. Design: a very short introduction. (Oxford University Press : 2005)
} 
berdasarkan faktor form dan function saja, melainkan juga menghadirkan faktor 'ethic' berupa hal-hal yang bersifat pengajaran kepada masyarakat. Membuat individu-individu dalam masyarakat menjadi manusia yang berkembang dengan memiliki kualitas 'manusia' yang meningkat. Sehingga akan terwujud sebuah tatanan masyarakat yang maju dalam aspek materi maupun spiritual. 


\section{DAFTAR PUSTAKA}

Heskett, John. 2005. Design: a very short introduction. New York : Oxford University Press.

Grimaldi, Joe. 2003. Inside the minds: the art of advertising: CEOs from BBDO, Mullin advertising \& more on generating creative campaigns \& building successful brands. Boston: Aspatore Books.

Slade, Giles. 2007. Made to break: technology and obsolescence in america. Cambridge : Harvard University Press

Karaiskos, D., Tzavellas, E., Balta, G., and Paparrigopoulos, T. 2010. P02-232 Social network addiction : a new clinical disorder? European Psychiatry [Online] 25, Sumber:

http://www.sciencedirect.com/science/article/pii/S0924933810708464 [diakses tanggal 4 maret 2011]

Purser, Ronald, E. The coming crisis in real-time environments: a dromological analysis, Sumber: http://online.sfsu.edu/ rpurser/revised/pages/DROMOLOGY.htm, diakses 10 Maret 2012.

ed. Hartmut, Rosa, and Scheuerman, William, E. 2009. High-speed society : social acceleration, power, and modernity. Pennsylvania: The Pennsylvania State University Press. 